J. Ris. \& Ap. Mat. Vol. 5 No. 1 (2021) pp. 60-67

Jurnal Riset dan Aplikasi Matematika

e-ISSN: 2581-0154

URL: journal.unesa.ac.id/index.php/jram

\title{
ANALISIS HASIL BICLUSTER ALGORITMA POLS PADA INTERAKSI PROTEIN MANUSIA DAN HIV-1
}

\author{
TesdiQ Prigel Kaloka ${ }^{1 *}$, Titin Siswantining ${ }^{2}$, Alhadi Bustamam $^{3}$ \\ ${ }^{1}$ Program Studi Teknik Informatika Politeknik Hasnur, ${ }^{2,3}$ Departemen Matematika FMIPA Universitas Indonesia \\ *tesdiq@ sci.ui.ac.id
}

\begin{abstract}
ABSTRAK
AIDS merupakan penyakit yang disebabkan oleh virus HIV-1. Protein merupakan bagian penting dari organisme yang memiliki beragam fungsi. HIV-1 dapat menyerang tubuh manusia karena adanya interaksi protein. Fungsi dan sifat interaksi protein dapat diketahui dengan mengelompokkan proteinprotein yang saling berinteraksi. Bicluster merupakan metode yang dapat digunakan untuk menyelesaikan permasalahan interaksi protein. Algoritma POLS merupakan algoritma bicluster yang menggunakan pendekatan teori graf. Data interaksi protein manusia dan HIV-1 dibagi menjadi dataset 1 dan dataset 2. Setiap dataset dianalisis tingkat kepadatan hasil bicluster Algoritma POLS. Penelitian berfokus pada pencarian tingkat kepadatan hasil bicluster Algoritma POLS terhadap interaksi protein manusia dan HIV-1. Dari hasil penelitian ini diperoleh presentase bicluster Algoritma POLS dengan tingkat kepadatan 1 pada dataset 1 sebesar 1,01\% dan pada dataset 2 sebesar 4,42\%, selain itu bicluster Algoritma POLS yang berukuran kecil $(2 \times 2$ dan $3 \times 3)$ lebih optimal karena memiliki tingkat kepadatan 1.
\end{abstract}

Kata Kunci: Interaksi Protein, Algoritma POLS, Bicluster

\begin{abstract}
AIDS is a disease caused by the HIV-1 virus. Proteins are an essential part of organisms that have various functions. HIV-1 can attack the human body due to protein interactions. The role and nature of protein interactions can be determined by grouping interacting proteins. Bicluster is a method that can be used to solve protein interaction problems. The POLS algorithm is a bicluster algorithm that uses a graph theory approach. Human protein interaction data and HIV-1 were divided into datasets one and dataset 2. Each dataset was analyzed for the density level of the POLS Algorithm bicluster. We focus on finding the density level of POLS Algorithm on the interaction of human and HIV-I protein. This study obtained percentage of dataset 1 with density level 1 is 1,01\% and dataset 2 with density 2 is 4,42\%, beside that, the small bicluster from POLS Alogrihtm is more optimal because it has density level of 1 .
\end{abstract}

Keyword: Protein Interaction, POLS Algorithm, Bicluster

\section{Pendahuluan}

Acquired Immunodeficiency Syndrome (AIDS) merupakan suatu penyakit yang disebabkan oleh virus Human Immunodeficiency Virus (HIV). HIV melemahkan kekebalan

2010 Mathematics Subject Classification: 92D20

Tanggal Masuk: 04-02-21; direvisi: 12-04-21; diterima: 29-04-21 
tubuh manusia secara perlahan, sehingga diagnosa penyakit AIDS terlambat (kekebalan tubuh sudah sangat lemah) dan banyak penderita AIDS yang meninggal [1]. Menurut Frankenberg [2] virus HIV terdiri dari 2 jenis, yaitu HIV-1 dan HIV-2.

HIV-1 merupakan virus yang terdiri dari susunan RNA. HIV-1 dapat menyerang kekebalan tubuh manusia karena terjadi proses interaksi protein. Sifat dan fungsi suatu protein dapat diketahui dengan mengelompokkan interaksi protein [3]. Sifat dan fungsi protein HIV-1 yang telah diketahui akan memudahkan pihak kesehatan untuk dapat menemukan cara penyembuhan penderita penyakit AIDS.

Permasalahan yang ditemui pada bidang kesehatan dan biologi adalah proses penelitian yang memakan waktu dan biaya yang cukup besar. Permasalahan tersebut dapat diatasi dengan bantuan Bioinformatika. Bioinformatika merupakan ilmu pengetahuan yang menggabungkan bioligis, kedokteran, matematika, statistika, dan teknik komputasi. Secara sederhana, bioinformatika membantu menyelesaikan permasalahan biologi, kedokteran, dan life science dengan menggunakan teori-teori matematika dan statistika yang selanjutnya dieksekusi menggunakan bantuan komputer [4]. Salah satu cabang Bioinformatika yang dapat menyelesaikan permasalahan pengelompokkan protein adalah bicluster. Bicluster merupakan suatu metode yang digunakan untuk mengelompokkan data-data ekspresi gen dikarenakan metode clustering biasa tidak dapat mencari pola kesamaan yang cocok [5]. Pada umumnya bicluster disamakan dengan clustering dua kali.

Bicluster merupakan suatu metode analisis yang digunakan untuk data-data biologis [6]. Algoritma bicluster telah banyak digunakan, salah satu algoritma bicluster pertama yang terkenal adalah Algoritma $\mathrm{CnC}$ (Cheng and Chruch), diambil dari nama penemu algoritma tersebut [7]. Beberapa algoritma bicluster yang sering digunakan antara lain: Qualitative Biclustering (QUBIC), FLOC, dan Binary Inclusion-Maximal (BiMax). QUBIC dan BiMax merupakan algoritma bicluster yang menggunakan pendekatan teori graf [5]. FLOC merupakan algorima yang menggunakan konsep probabilitas [8].

Algoritma Bicluster terbaru dikemukakan oleh Wang [9] yang disebut dengan Algoritma POLS. Algoritma POLS menggunakan pendekatan teori graf dan teori biclique seimbang. Berdasarkan penelitian Bustamam [3], hasil bicluster Algoritma POLS menunjukkan adanya protein yang tidak berinteraksi pada satu bicluster. Kemampuan suatu Algortima Bicluster dalam mengelompokkan data diukur dengan tingkat kepadatannya, semakin tinggi tingkat kepadatannya, maka semakin baik algoritma tersebut. Sehingga penelitian ini berfokus pada tingkat kepadatan interaksi setiap bicluster Algoritma POLS terhadap interaksi protein manusia dan HIV-1. Harapan kedepannya penggunaan bicluster dapat membantu bidang kesehatan untuk melakukan penelitian lebih mendalam dari hasil bicluster.

\section{Tinjauan Pustaka}

\subsection{Bicluster}

Biclsuter pertama kali dikemukakan oleh Cheng \& Church [8] dan lebih dikenal dengan clustering secara baris dan kolom. Pada awalnya, biclsuter digunakan untuk mencari suatu subset dari dari sebuah gen yang saling berkaitan [5]. Konsep pencarian bicluster adalah dengan mengelompokkan nilai-nilai yang memiliki keterhubungan menjadi suatu sebuah subset dari data yang ada.

Diberikan suatu matriks $A(D, C)$ dengan $D$ adalah suatu himpunan data $D=$ $\left\{I_{1}, I_{2}, I_{3}, \ldots, I_{D},\right\}$ dan $C$ suatu himpunan fitur $C=\left\{J_{1}, J_{2}, J_{3}, \ldots, J_{C}\right\}$. Sebuah bicluster didefinisikan sebagai: 


\section{Definisi 1}

Sebuah bicluster merupakan submatriks $M(I, J)=\left[m_{i, j}\right]$ dengan $i \in I, j \in J$ adalah matriks $A(D, C)$ dengan $I \in D$ dan $J \in C$ [5]. Secara sederhana, bicluster merupakan pencarian submatriks dari data yang digunakan (Persamaan 1).

$$
A(D, C)=\left[\begin{array}{ccccc} 
& J_{1} & J_{2} & \cdots & J_{C} \\
I_{1} & m_{11} & m_{12} & \cdots & m_{1 C} \\
I_{2} & m_{21} & m_{22} & \cdots & m_{2 C} \\
\vdots & \vdots & \vdots & \ddots & \vdots \\
I_{D} & m_{D 1} & m_{D 2} & \cdots & m_{D C}
\end{array}\right]
$$

\subsection{Algoritma POLS}

Algoritma POLS merupakan suatu algoritma pencarian bicluster yeng menggunakan pendekatan teori graf. Hasil bicluster Algoritma POLS merupakan sebuah biclique seimbang. Biclique seimbang merupakan suatu graf bipartit lengkap dengan jumlah partisi busur yang sama.

Bicluster hasil Algoritma POLS dibentuk dengan menggunakan beberapa tahap. Tahaptahap tersebut dinamakan kandidat, addset, dropset, pscore, dan addrule. Kandidat merupakan tempat untuk menyimpan solusi hingga proses iterasi selesai. Addset merupakan himpunan suatu semesta yang akan ditambahkan ke kandidat. Dropset merupakan subset dati kandidat. Pscore merupakan nilai dari setiap pasang addset. Addrule merupakan proses pemilihan pasangan busur terbaik dari addset [9]. Penjelasan Algoritma POLS dapat lebih dipahami pada Tabel 1 .

Tabel 1: Algoritma POLS

\begin{tabular}{|c|c|c|}
\hline Masukan & : & Graf Bipartit \\
\hline 1 & : & Inisialisasi addset, dropset, $\operatorname{dan} S^{*}=S$ \\
\hline \multicolumn{3}{|r|}{ - } \\
\hline 2 & : & $\begin{array}{l}\text { Pilih sepasang simpul }(u, v) \text { dari addset menggunakan } \\
\text { addrule }\end{array}$ \\
\hline 3 & : & Masukkan pasangan simpul $(u, v)$ ke $S=S \cup(u, v)$ \\
\hline Hingga & : & Addset $=\varnothing$ \\
\hline 4 & : & Jika $|S|>\left|S^{*}\right|$, maka $S^{*}=S$ \\
\hline 5 & : & Hilangkan pasangan simpul $(u, v)$ pada dropset \\
\hline Keluaran & : & Bicluster \\
\hline
\end{tabular}

Jika kandidat solusi dinotasikan sebagai $S=\left(U^{S}, V^{S}, E^{S}\right)$. Misal Diberikan suatu graf bipartit $G=G(U, V, E)$ dengan simpul $U$ dan $V$ adalah $U=\left\{u_{1}, u_{2}, u_{3}, \ldots, u_{n}\right\}$ dan $V=$ $\left\{v_{1}, v_{2}, v_{3}, \ldots, v_{n}\right\}$ serta busur $E$ adalah $E=\left\{e_{1}, e_{2}, e_{3}, \ldots, e_{n}\right\}$ maka menurut Wang [9] definisi addset, dropset, dan pscore adalah

$$
\begin{gathered}
\text { Addset }=\left\{(u, v) \in \mid u \notin U^{S}, u \in N\left(v^{\prime}\right) ; \forall v^{\prime} \in V^{S}, v \notin V^{S}, v \in N(u) ; \forall u^{\prime} \in U^{S}\right\} \\
\text { Dropset }=\left\{(u, v) \in E \mid u \in U^{S}, v \in V^{S}\right\} \\
\operatorname{pscore}(u, v)=\operatorname{score}_{l b}(u, v)+\left\lfloor\frac{\text { score }_{u b}}{2}\right\rfloor
\end{gathered}
$$


dengan $\operatorname{score}_{l b}(u, v)=1 \quad$ dan $\quad \operatorname{score}_{u b}(u, v)=\min \{|N(v)|-|N(v) \cap S|,|N(u)|-$ $|N(u) \cap S|\}$. Nilai pscore terbesar disebut add rule.

\subsection{Data}

Data interaksi protein manusia dan HIV-1 merujuk pada [10] diperoleh melalui situs NCBI (National Centre for Biotechnology Information). Data dapat diakses melalui https://www.ncbi.nlm.nih.gov/genome/viruses/retroviruses/hiv-1/interactions/browse/. Data tersebut merupakan sebuah tabel yang terdiri dari protein manusia, ID gen manusia, simbol gen manusia, protein HIV-1, ID gen HIV-1, symbol gen HIV-1, dan jenis interaksi. Data tersebut memiliki 16215 interaksi protein manusia dan HIV-1, 3797 protein manusia, 23 protein HIV, dan 130 jenis interaksi.

\section{Metode Penelitian}

Proses penelitian dibagi menjadi tiga tahap utama, yaitu: praproses data, implementasi, dan analisis. Praproses data merupakan tahapan transformasi data yang dimiliki menjadi sebuah dataset yang siap untuk diimplementasikan pada program. Tahap implementasi merupakan proses penggunaan Algoritma POLS pada dataset yang telah dimiliki. Tahap analisis merupakan proses untuk mengetahui tingkat kepadatan interaksi hasil bicluster. Keseluruhan proses penelitian dapat dilihat pada Gambar 1.

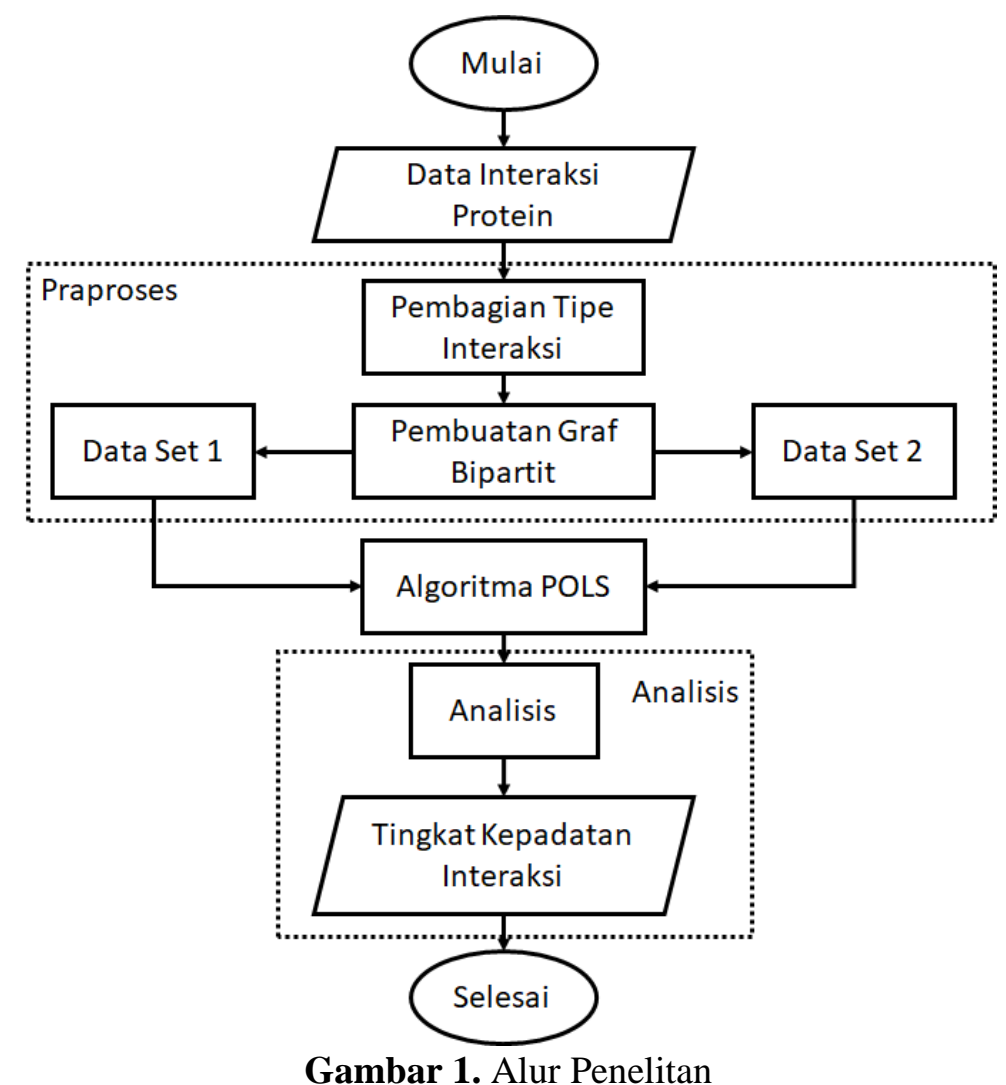

Berdasarkan Gambar 1, tahap praproses terdiri dari empat bagian. Pembagian tipe interaksi merupakan proses pembagian 130 jenis interaksi menjadi tiga tipe. Terdapat 69 jenis interaksi pada tipe pertama, 48 jenis interaksi pada tipe kedua, dan 13 jenis interaksi pada tipe ketiga. Pembagian seluruh jenis interaksi mengikuti Algoritma Dataset penelitian [11]. Tipe 
pertama merupakan interaksi dari HIV-1 ke manusia. Tipe kedua merupakan interaksi dari manusia ke HIV-1. Tipe ketiga merupakan interaksi dua arah. Pembuatan graf bipartite dilakukan dengan memberikan nilai pada tipe interaksi. Berikan nilai 1 apabila tipe pertama, nilai -1 apabila tipe kedua dan $\mathrm{X}$ apabila tipe ketiga dan 0 apabila tidak ada interaksi. Dataset 1 merupakan kumpulan nilai 0, 1 dan X. Dataset 2 merupakan kumpulan nilai 0, -1, dan X.

Tahapan Algoritma POLS merupakan implementasi dari langkah-langkah Algoritma POLS dan teori graf. Tahapan analisis merupakan perhitungan kepadatan interaksi dengan menggunakan perbandingan sederhana.

\section{$4 \quad$ Hasil dan Pembahasan}

Hasil bicluster Algoritma POLS merupakan sebuah biclique seimbang. Biclique seimbang merupakan subset dari suatu graf bipartit dengan jumlah busur yang sama. Apabila $\boldsymbol{G}=\boldsymbol{G}(\boldsymbol{U}, \boldsymbol{V}, \boldsymbol{E})$ merupakan representasi dari dataset, maka hasil bicluster $\boldsymbol{H}=\left(\boldsymbol{U}^{\prime}, \boldsymbol{V}^{\prime}, \boldsymbol{E}^{\prime}\right)$ merupakan subset dari subset dari dataset $(\boldsymbol{H} \subseteq \boldsymbol{G})$, maka $\left|\boldsymbol{U}^{\prime}\right|=\left|\boldsymbol{V}^{\prime}\right|$. Pada penerapan bicluster, biclique seimbang mengharuskan terpenuhinya dua syarat: jumlah baris dan kolom sama; serta nilai baris dan kolom harus terisi (bukan 0). Sehingga submatriks merupakan matriks persegi. Selanjutnya entri-entri submatriks tersebut akan dianalisis tingkat kepadatan interaksi protein. Kepadatan interaksi merupakan perbandingan nilai 1 dan 0 pada submatriks hasil bicluster. Semakin tinggi tingkat kepadatan, maka hasil bicluster semakin baik.

Data penelitian ini dibagi menjadi 2, yaitu Dataset 1 dan Dataset 2, sehingga diperoleh hasil untuk dataset 1 dan dataset 2. Selanjutnya akan dijelaskan untuk hasil bicluster setiap dataset.

\subsection{Dataset 1}

Dataset 1 menghasilkan 297 bicluster dengan bicluster berukuran $2 \times 2$ sebanyak 171, $\mathbf{3} \times \mathbf{3}$ sebanyak $35, \mathbf{4} \times \mathbf{4}$ sebanyak $78, \mathbf{5} \times \mathbf{5}$ sebanyak $5, \mathbf{6} \times \mathbf{6}$ sebanyak 7 , dan satu bicluster berukuran $7 \times \mathbf{7}$. Hasil bicluster dataset 1 dapat dilihat pada Tabel 2 . Terlihat bahwa seluruh hasil bicluster merupakan submatriks dari dataset 1 dengan jumlah baris dan kolom sama (matriks persegi).

Tabel 2: Hasil Bicluster Dataset 1

\begin{tabular}{|c|c|}
\hline Ukuran Bicluster & Jumlah \\
\hline $2 \times 2$ & 171 \\
\hline $3 \times 3$ & 35 \\
\hline $4 \times 4$ & 78 \\
\hline $5 \times 5$ & 5 \\
\hline $6 \times 6$ & 7 \\
\hline $7 \times 7$ & 1 \\
\hline
\end{tabular}

Seluruh 297 bicluster kemudian dilihat tingkat kepadatan bicluster. Tingkat kepadatan bicluster diperoleh dengan cara:

$$
D=\frac{n}{N}
$$


dengan $D$ merupakan tingkat kepadatan bicluster, $n$ adalah jumlah entri bicluster yang tak 0 dan $N$ adalah total entri bicluster.

Tabel 3: Tingkat Kepadatan Bicluster Dataset 1

\begin{tabular}{|c|c|c|}
\hline Jumlah Bilcuster & Presentase & Tingkat Kepadatan \\
\hline 228 & $\mathbf{7 6 , 7 7} \%$ & $>\mathbf{0 , 5}$ \\
\hline 22 & $\mathbf{7 , 4 1} \%$ & $>\mathbf{0 , 7 5}$ \\
\hline 3 & $\mathbf{1 , 0 1} \%$ & $>\mathbf{1}$ \\
\hline
\end{tabular}

Berdasarkan Persamaan 5 dan data Tabel 2, terdapat 228 bicluster dengan tingkat kepadatan lebih dari 0,5. Jumlah ini setara dengan 76,77\% dari total hasil bicluster. Dari 297 bicluster, terdapat 22 bicluster $(7,41 \%)$ yang memiliki tingkat kepadatan lebih dari 0,75 dan hanya terdapat $3(1,01 \%)$ bicluster yang memiliki tingkat kepadatan 1 . Rangkuman tingkat kepadatan bicluster dapat dilihat pada Tabel 3.

21 dari 22 bicluster dengan tingkat kepadatan lebih dari 0,75 masing-masing merupakan matriks $\mathbf{2} \times \mathbf{2}$ dan hanya terdapat satu bicluster yang berukuran $\mathbf{3} \times \mathbf{3}$. Selain itu, bicluster berukuran $3 \times 3$ tersebut juga merupakan bicluster dengan tingkat kepadatan 1. Sehingga pada bicluster dengan tingkat kepadatan 1, terdapat 2 bicluster $2 \times 2$ dan 1 bicluster $3 \times 3$.

\subsection{Dataset 2}

Proses dan cara implementasi pada dataset 2 sama dengan dataset 1, sehingga diperoleh: 203 bicluster dengan bicluster berukuran $\mathbf{2} \times \mathbf{2}$ sebanyak 110, $3 \times \mathbf{3}$ sebanyak $24, \mathbf{4} \times \mathbf{4}$ sebanyak 59, $\mathbf{5} \times \mathbf{5}$ sebanyak 5, $\mathbf{6} \times \mathbf{6}$ sebanyak 4, dan satu bicluster berukuran $\mathbf{7} \times \mathbf{7}$. Ukuran dan jumlah bicluster dapat lebih mudah dipahami melalui Tabel 4.

Tabel 4: Hasil Bicluster Dataset 2

\begin{tabular}{|c|c|}
\hline Ukuran Bicluster & Jumlah \\
\hline $2 \times 2$ & 110 \\
\hline $3 \times 3$ & 24 \\
\hline $4 \times 4$ & 59 \\
\hline $5 \times 5$ & 5 \\
\hline $6 \times 6$ & 4 \\
\hline $7 \times 7$ & 1 \\
\hline
\end{tabular}

Terdapat 11 bicluster dengan tingkat kepadatan 1, 17 bicluster dengan tingkat kepadatan lebih dari 0,75, dan 182 bicluster dengan tingkat kepadatan lebih dari 0,5. Presentase bicluster dengan tingkat kepadatan lebih dari 0,5, lebih dari 0,75, dan 1 secara berturut-turut adalah $89,65 \%, 8,37 \%$, dan 5,42\%. Presentase tingkat kepadatan bicluster dapat pula dilihat pada Tabel 5. Seluruh bicluster dengan tingkat kepadatan 1 dan lebih dari 0,75 berukuran $2 \times 2$. 
Tabel 5: Tingkat Kepadatan Bicluster Dataset 2

\begin{tabular}{|c|c|c|}
\hline Jumlah Bicluster & Presentase & Tingkat Kepadatan \\
\hline 182 & $\mathbf{8 9 , 6 5} \%$ & $>\mathbf{0 , 5}$ \\
\hline 17 & $\mathbf{8 , 3 7} \%$ & $>\mathbf{0 , 7 5}$ \\
\hline 11 & $\mathbf{5 , 4 2} \%$ & $\mathbf{1}$ \\
\hline
\end{tabular}

\subsection{Analisis}

Berdasarkan Tabel 3 dan 5, presentase untuk $\boldsymbol{D}=\mathbf{1}$ tidak lebih dari $\mathbf{6 \%}$, bahkan pada Dataset 1 (Tabel 3) hanya mencapai 1,01\%. Selain itu, berdasarkan penjelasan bicluster Dataset 1 dan 2, hampir seluruh bicluster dengan $\boldsymbol{D}=\mathbf{1}$ berukuran $\mathbf{2} \times \mathbf{2}$. Hanya terdapat 1 bicluster berukuran $\mathbf{3} \times \mathbf{3}$ pada Dataset 1 . Sehingga dapat dikatakan bahwa, dari total 400 bicluster, hanya terdapat 14 bicluster yang memenuhi kriteria submatriks persegi dan memiliki tingkat kepadatan sama dengan 1. Berdasarkan Tabel 2 dan 4, hanya terdapat satu bicluster yang berukuran $7 \times 7$ pada masing-masing Dataset 1 dan 2 . Tingkat kepadatan bicluster tersebut tidak mencapai 0,5 sehingga tidak dapat dikatakan bicluster yang baik.

Pada permasalahan interaksi protein manusia dan HIV-1, jumlah (ukuran) protein manusia dan HIV-1 jauh berbeda. Protein manusia berjumlah 3797 dan HIV-1 berjumlah 23. Perbedaan jumlah yang signifikan tersebut menyebabkan hasil Algoritma POLS didominasi dengan bicluster berukuran $2 \times \mathbf{2}$. Dilihat dari beberapa pemaparan, maka Aloritma POLS lebih baik menghasilkan bicluster berukuran kecil $(2 \times \mathbf{2}$ dan $\mathbf{3} \times \mathbf{3})$. Hal ini dikarenakan hanya bicluster berukuran kecil yang memiliki tingkat kepadatan 1. Selain itu Algoritma POLS lebih cocok untuk permasalahan dengan data yang seimbang (jumlah simpul yang sama).

\section{Kesimpulan}

Berdasarkan hasil penelitian, dari 400 bicluster, terdapat 14 bicluster yang memiliki tingkat kepadatan 1. Kemudian presentase hasil bicluster Algoritma POLS dengan tingkat kepadatan 1 pada dataset 1 sebesar $1,01 \%$ dan pada dataset 2 sebesar 4,42\%. Bicluster Algoritma POLS yang berukuran kecil $(2 \times 2$ dan $3 \times 3)$ lebih optimal karena memiliki tingkat kepadatan 1.

\section{Daftar Pustaka}

[1] A. Trkola, "HIV - host interactions : vital to the virus and key to its inhibition," 2004, doi: 10.1016/j.mib.2004.06.002.

[2] E. Frankenberg, “基因的改变NIH Public Access,” Bone, vol. 23, no. 1, pp. 1-7, 2012, [Online]. Available: https://www.ncbi.nlm.nih.gov/pmc/articles/PMC3624763/pdf/nihms412728.pdf.

[3] A. Bustamam, T. Siswantining, T. P. Kaloka, and O. Swasti, "Application of BiMax, POLS, and LCM-MBC to Find Bicluster on Interactions Protein between HIV-1 and Human," Austrian J. Stat,, vol. 49, no. 3, pp. 1-18, Feb. 2020, doi: 10.17713/ajs.v49i3.1011. 
[4] G. Ardaneswari, A. Bustamam, and D. Sarwinda, "Implementation of plaid model biclustering method on microarray of carcinoma and adenoma tumor gene expression data," J. Phys. Conf. Ser., vol. 893, no. 1, 2017, doi: 10.1088/1742-6596/893/1/012046.

[5] A. Mukhopadhyay, U. Maulik, and S. Bandyopadhyay, "On Biclustering of Gene Expression Data On Biclustering of Gene Expression Data," no. December 2013, 2010, doi: 10.2174/157489310792006701.

[6] G. Ardaneswari, A. Bustamam, and T. Siswantining, "Implementation of parallel kmeans algorithm for two-phase method biclustering in Carcinoma tumor gene expression data," AIP Conf. Proc., vol. 1825, 2017, doi: 10.1063/1.4978973.

[7] Y. Cheng and G. M. Church, "Biclustering of expression data.," Proc. Int. Conf. Intell. Syst. Mol. Biol., vol. 8, pp. 93-103, 2000.

[8] J. Yang, H. Wang, W. Wang, and P. Yu, "Enhanced biclustering on expression data," Proc. - 3rd IEEE Symp. Bioinforma. Bioeng. BIBE 2003, pp. 321-327, 2003, doi: 10.1109/BIBE.2003.1188969.

[9] Y. Wang, S. Cai, and M. Yin, "New heuristic approaches for maximum balanced biclique problem," Inf. Sci. (Ny)., vol. 432, pp. 362-375, 2018, doi: 10.1016/j.ins.2017.12.012.

[10] A. Mukhopadhyay, S. Ray, and U. Maulik, "Incorporating the type and direction information in predicting novel regulatory interactions between HIV-1 and human proteins using a biclustering approach," BMC Bioinformatics, vol. 15, no. 1, 2014, doi: 10.1186/1471-2105-15-26.

[11] T. P. Kaloka, A. Bustamam, D. Lestari, and W. Mangunwardoyo, "POLS algorithm to find a local bicluster on interactions between HIV-1 proteins and human proteins," AIP Conf. Proc., vol. 2084, no. March, 2019, doi: 10.1063/1.5094280. 